\title{
Assessing Arms Makers' Corporate Social Responsibility
}

Edmund F. Byrne

\begin{abstract}
Corporate social responsibility (CSR) has become a focal point for research aimed at extending business ethics to extra-corporate issues; and as a result many companies now seek to at least appear dedicated to one or another version of CSR. This has not affected the arms industry, however. For, this industry has not been discussed in CSR literature, perhaps because few CSR scholars have questioned this industry's privileged status as an instrument of national sovereignty. But major changes in the organization of political communities call traditional views of sovereignty into question. With these considerations in mind I assess the U.S. arms industry on the basis of CSR requirements regarding the environment, social equity, profitability, and use of political power. I find that this industry fails to meet any of these four CSR requirements. Countering a claim that these failings should not be held against arms manufacturers because their products are crucial to national defense, I contend that many of these companies function not as dutiful agents of a nation-state but as politically powerful entities in their own right. So, I conclude, they should be held responsible for the foreseeable consequences that flow from use of their products. This responsibility should include civil liability and, in cases involving war crimes and violations of human rights, responsibility under international human rights standards.
\end{abstract}

KEY WORDS: corporate social responsibility, arms industry, liability, human rights

Edmund F. Byrne is emeritus professor of philosophy, Indiana University, and a section editor and sometime contributor to the Journal of Business Ethics. His specialties: philosophy of work and social and political philosophy. Recent publications in the former field include "Work" in the Encyclopedia of Science, Technology, and Ethics, and in the latter field three articles that examine the US government's unpublicized geopolitical motives for its military action in the Middle East.

\section{Introduction}

Over the last century in and beyond the United States large corporations attained almost complete autonomy in law and in cultural understandings as well (Cray and Drutman, 2005). Prominent abuses of this insularity led to the emergence of business ethics, which has focused on moral issues within the boundaries of a corporate entity. But some business ethicists take the social and political context into account as they assert stakeholders' rights or call for socially responsible investing (SRI) and/or corporate social responsibility (CSR). Scholars differ regarding what kinds of issues should be included under CSR but they have considered the following aspects of a company's business activities: how well it maximizes profit, satisfies social demands, honors ethical values, and uses political power (Garriga and Melé, 2004), and how well it protects the environment and complies with legal constraints (Carroll, 1991; Collins and Porras, 2002; Gettler 2005). Taken together, these various approaches to CSR reach beyond laissez faire. But views as to how bound management should be by CSR norms range from mandatory and enforced to hortatory and discretionary. Whence various critiques and corrective proposals.

Some cite empirical data to raise doubts about the efficacy of CSR (Heath and Norman, 2005; Vogel, 2005;). Others focus on the way some companies turn CSR into a public relations coup (Kapelus, 2004); and in so doing they invite cynical evaluations of the movement (Crook, 2005; Doane, 2005; Mokhiber and Weissman, 2005). Attempting to obviate flaws in CSR's efficacy, some scholars propose criteria for determining if a company's claim to CSR is legitimate (Graafland et al., 2004; Pava and Krausz, 1997); another ties the efficacy of CSR to "stakeholder activism" in "a responsible society" (Jeurissen, 2004), and another, to a global agreement 
(Hopkins, 2003). Corporate leaders respond to this learned discourse by signing such declarations of principle as the UN Global Compact, 1999, which now has several hundred signatories, or the "Global Corporate Citizenship" joint statement signed by twenty-four MNCs in New York in 2002. They also support the annual Dow Jones Sustainability Index (DJSI), which includes special criteria for companies such as armaments manufacturers whose artefacts cause foreseeable and preventable harm (see also Gowri, 2004; Hopkins, 2003, pp. 154-156).

These developments notwithstanding, few if any CSR studies address the arms industry directly. This lacuna is due in part to the issue's built-in oxymoron (Baker, 2005) but far more, I believe, to centuriesold assumptions about political sovereignty, including the nation-state's absolute authority and responsibility regarding war and weapons. Left unchallenged, these assumptions exonerate the arms industry of all responsibility for what is done with its products. But an appeal to sovereignty should not exempt the arms industry from CSR because, as critical international relations scholars tell us, the paradigmatic nation-state with absolute sovereignty is quite recent in historical terms and may become a null class (Linklater, 1998; see also Matten et al., 2003), even as the quasi-sovereignty of MNCs is increasing (Cray and Drutman, 2004, 2005) and causing negative externalities. ${ }^{1}$ So it is encouraging that peace-oriented NGOs are attempting to develop both CSR criteria and international laws of human rights into legally binding norms.

Arms industry actors are well aware of this normative agenda, but they see themselves as being outside the purview of CSR. Corroborating this view is the fact that their harm-facilitating business enjoys the collaboration, endorsement, and generosity of its principal customer, that is, government. This has been the situation since organized political entities began warring against one another to determine which powers will control which parts of the world (Porter, 1994, ch. 4). Such government reliance on military might became a defining characteristic of the arms industry during the wars of the twentieth century; and since the Cold War the industry has become a paradigm of corporate dominance. From within the socially constructed world of a nation-state, however, the traditional concept of absolute sovereignty retains its hold. In such a world it is hard to get a hearing for any claim that an industry devoted to "national defense" could possibly be involved in fundamentally (not just incidentally) unethical activity.

This Hobbesian ideology fails on its own terms because (a) the primary beneficiaries of nation-state arms procurement are not citizens needing protection but private corporations needing revenue and (b) many weapons are neither sold to nor used by nation-states. To show the moral significance of these assertions I will assess the CSR status of the arms industry, especially in the United States, with regard to (1) environmental quality, (2) social equity, (3) profitability (EORM, n.d.; Goldberg, 2001; Zwetsloot, 2003), and especially (4) use of political power (Hopkins, 2003; Hopkins and Hopkins, 2002). This assessment will show that arms industry products cause negative externalities to planet and people and that their weapons businesses are profitable only because of amoral government priorities that the industry fosters and largely controls. My conclusion: corporations in this industry violate CSR standards and for this reason are not entitled to unfettered autonomy but should be made subject to appropriate legal constraints (see Davis, 1960). This means that arms manufacturers should be held liable for foreseeable negative externalities brought about by users of their weapons if these involve violations of human rights.

In working through this agenda, I will at times appeal to a distinction between Westphalian and post-Westphalian political arrangements. The meaning of these terms should become clearer from their use in various contexts. For now it suffices to indicate that their meanings derive from the Treaty of Westphalia (1648) which set in motion a political process that deems nation-states to be sovereign entities singularly empowered to use and control violence. Though still canonical for most political scientists, this Westphalian doctrine is no longer relevant to many types of organized political violence, thus inviting introduction of the term post-Westphalian.

\section{The arms industry would fail a CSR environmental requirement}

Weapons of war harm environments into which they are introduced. Under some possible set of 
circumstances they could conceivably benefit the environment, though I fail to see how. Someone might also assert that war-caused harm to the environment might not be irreversible. It is difficult to imagine, though, that anyone would seriously claim that no military weapon harms the environment.

The extent of environmental damage a weapon might cause depends in large measure on the level of military technology it involves together with a claim, now refuted, that the environment has no owner so may be used at no cost. Moreover, the scope of harm caused by a weapon extends beyond the effects of its actual use in war to numerous places where it is produced, tested, stored, or disposed of. Few would dispute that each of these activities in connection with nuclear weapons has had devastating effects on the environment. Chemical and biological weapons are no less problematic (Harigel, 2001; Mnutsakanian, 1997). Artillery testing has also done catastrophic damage to numerous ecologically precious sites including a once beautiful island in Puerto Rico, nature preserves in South Africa, a lake used by migratory birds in Quebec, and large areas of Panama, Nevada, and Cape Cod in Massachusetts. Military organizations as well as their supporting agencies, e.g., the US Department of Energy, rarely disclose data about these matters. But some private groups have reported the environmental consequences of weaponry in some detail (Ardley and Grant, n.d.; Brauer, 2000; Peluso and Watts, 2001; Savage, 2000; Wagner, 2003); and some public funds are now being expended, e.g., by the US Environmental Protection Agency, to restore weapondevastated areas (see also Gariépy, 2001).

Unlike the large weapons systems that technology has made available over the last several centuries, small arms and even conventional weapons might not cause irreversible environmental harm. But this is a factual issue. The question of principle is whether any arms manufacturer or trader should be held liable for demonstrable environmental degradation that can be traced directly to the weapons it makes or sells. I respond to this in the affirmative, provided that those engaged in arms transfers know or should know that their products are hostile to the environment, e.g., by making it uninhabitable or accessible only at great risk. Both because of and apart from these consequences, though, is the direct impact of "collateral damage" on human beings, namely, that weapons used militarily often violate human rights, sometimes catastrophically.

\section{The arms industry would fail a CSR social equity requirement}

Most proponents of SRI and of versions of CSR that recognize the validity of stakeholder theory require that a corporation's products and services not inflict harm unduly on people in societies where they are situated. This includes points of origin but must include points of arrival as well. A globalized perspective is especially appropriate with regard to the US arms industry, because it seeks to apply everywhere the individualist interpretation of a right to bear arms that already obfuscates moral assessments of corporate liability in the United States. So as applied to the arms industry the CSR social equity requirement must take "local" to mean any place where this industry's products are located. For, horribly detrimental wars are currently being fought in many places with arms typically provided from afar.

In these conflicts international standards of warfare are of limited use; so there is need for additional norms that will extend protection on an emergency basis to those who are most vulnerable in these conflicts, especially civilians and indentured child soldiers. This is clearly the position of organizations seeking to maintain and expand civil society as a counter-force to government prerogatives. It is also the position of many corporations, at least with regard to their own workplaces. In keeping with the old maxim about what is good for goose and gander respectively, I offer some data relevant to this observation.

Later I will discuss national defense and costbenefit arguments for military expenditures in the US. These arguments apply only tangentially, however, to the small arms bazaar. For this specialized trade in killing implements is not easily vindicated by an appeal to national defense. An attempt is made to do just that of course, by claiming, "it is better to fight them over there rather than here." But the egocentric reasoning at work here rarely suffices to justify the negative externalities such wars 
unleash. Similarly, an appeal to commercial benefits is consequentially invalidated by the human rights violations these weapons help bring about. Consider, then, the weapons at issue and the effects of using them.

Small arms include handguns, carbines, assault rifles, rocket-propelled grenades, light mortars, and shoulder-fired missiles. There are presently an estimated 500-550 million small arms in circulation around the world. Spokespersons for the arms industry contend that caveat emptor should govern this proliferation of weapons, as though what is at issue is nothing more serious than the occasional misuse of an inherently wholesome product. This see-no-evil approach to merchandised mayhem is personified by such arms profiteers as Samuel Cummings, Victor Bout (Farah and Braun, 2006), and Gus van Kouwenhoven, whose modus operandi is fictionalized in the film Lord of War (2005). To market this business globally the National Rifle Association (NRA) has apparently been earning enough from sellers to overcome its onetime budget deficit estimated at $\$ 100$ million (Goldring, 1999; Morton, 2006; NYT, 21 Dec. 2003; Econ, 8 May 1998). ${ }^{2}$ Though these weapons account for only $\$ 10$ billion worth of the $\$ 850$ billion/year of military expenditures, the costs incurred by their use are overwhelming.

One cost is surely the support these weapons give to buyers who are fighting a small war and for whom such wars are a way of life, a business. As described by William D. Hartung,

More often than not, today's wars are multi-sided affairs in which militias, gangs, and self-anointed "rebels" engage in campaigns of calculated terror, civilian targets are fair game, and the laws of war are routinely ignored... (This is) a new post-Cold War model of "rebellion," a form of irregular warfare that can be sustained without a big-power patron and frequently without the support of the majority of the people in the target nation... (It is, in effect,) war as plunder (2001, pp. 80, 81).

A second cost consists of the fact that the easy availability of small arms facilitates conflicts, heightens their severity and longevity. Small arms, moreover, are involved far more often in violations of human rights and humanitarian laws than are such major conventional weapons systems as planes and helicopters (Singer, 2003, pp. 54-56). Indeed, according to one study, small arms were the only weapons used in 46 of 49 major conflicts in the 1990 s, in which $80-90 \%$ of those killed were civilians (as compared to 5\% in WW I), and are the single most important cause of the upsurge in refugees (Klare, 1999). Because small arms are comparatively light, they can be used by children, of whom over 300,000 under the age of 18 are now serving as soldiers (London, 2005, p. 1).

Appalled by these data, a large coalition of NGOs is seeking to stem the tide of human rights violations, including those involving the use of small arms. At the Ottawa Convention in 1997 this coalition presented a treaty banning landmines, which many nations (not including the US) have signed. And it has since moved on to address other contributors to unjustifiable bloodletting capability. It is now seeking regulations that will hold accountable for human rights violations (1) recipient users of the arms, (2) individuals who engage in transferring them, and (3) governments that authorize the transfers.

Recipients who are extreme violators can be brought before an international court of justice; but efforts to further limit individual users has been blocked by US insistence that the right to bear arms is sacrosanct (NYT, 28 June 2006 ). Other proposals would apply human rights criteria to arms traders if they violate arms embargoes or engage in actions proscribed under such criminal law concepts as command responsibility and complicity (CHD, 2006; Misol, 2004; Wood, 2006). Perhaps eventually governments will be held accountable under international law for authorizing arms transfers that can reasonably be expected to result in violations of human rights; but not yet. In 1991 an NGO coalition began a "Control Arms" campaign to bring about a small arms trade treaty. Many countries were prepared to sign this treaty at a UN conference in 2006; but NRA personnel held all three US appointments at this conference and severely distorted the UN's objective in an extensive media campaign (CDI, 2006). No treaty was signed.

Even if it had been signed, it would have been just one step towards a world in which committing acts of violence is not a protected right. Legal frameworks for such a world are being developed; their implementation will take time. Meanwhile, certain non-state actors already ban possession and use of 
weapons in places they control. These are corporations, including some that are engaged in arms production. Some companies prohibit employees from having weapons on site without explicit permission. ${ }^{3}$ Some ban weapons outright with no mention of exceptions, and some even extend their ban beyond their proprietary premises. ${ }^{4}$ At least one arms manufacturer, General Dynamics (n.d., p. 16) bans weapons on its premises, whereas firearms producer Sturm, Ruger \& Company, Inc. (n.d.) apparently does not.

Some corporations, then, do ban weapons; and bills are pending in some states in the US to make such bans mandatory. Meanwhile, gun rights organizations such as the NRA are actively lobbying state governments to invalidate workplace weapons bans. These organizations fail to realize, apparently, that such bans are based on the very foundations of capitalism, namely, ownership and property rights. Moreover, the entities imposing these bans are not just ordinary owners they are politically powerful organizations that may have wealth and influence greater than many nation-states. As such, they exemplify a major component of a post-Westphalian world: politically powerful non-state actors. So perhaps the way they restrict access to weapons where they are in control should be emulated by other actors, both state and non-state, who have no less of a need to protect their interests and their people. Such restrictions would be fully in accord with traditional Westphalian understandings; but as it happens these understandings may not always coincide with the quest for profit.

\section{The arms industry would fail a CSR profitability requirement}

Considering the multi-billion dollar revenues some defense contractors generate, it might seem foolish to contend that the arms industry is not profitable. But to a great extent this industry depends for its working capital on the continuous input of government funds obtained from taxpayers and creditors. Indeed, this has for centuries been a defining characteristic of companies dedicated to providing military needs, so much so that the history of taxation is inseparable from that of warfare (Porter, 1994, esp. pp. 114-118). So if one takes profitability in its usual sense as a favorable return on investment in, development and marketing of goods and/or services, then the arms industry is not profitable. This being the case, a consistent free-market conservative who eschews managerial responsibility for any CSR objective other than profit (Henderson, 2005) would be disappointed. A Keynesian economist, though, might interpret the industry's government subsidies, as pump priming that might not be fatal to a claim of profitability. But, technical issues aside, a Keynesian economist would endorse intervention in the economy only if it is done in a way that improves societal well-being. So can one excuse the arms industry for not complying with the CSR profitability requirement because the industry's goods and services are the sine qua non of national defense? This line of reasoning appeals to some, of course, but it is faulty, as can be seen by considering how poorly the arms industry complies with the CSR requirement that companies use political power equitably.

\section{The arms industry would fail a CSR use of political power requirement}

Arms industry output is friendly neither to the natural environment nor to social equity, and can be considered profitable only by ignoring what historians call the triad of army, taxes, and bureaucracy (Porter, 1994, pp. 116-118). The issue, then, is whether these failings can be discounted because weapons providers are inseparable from government and its purportedly sovereign responsibilities. The long historical interdependence of nation-states and weapons makers (Porter, 1994, chs. 5-7) supports the inseparability claim. But (1) arms makers today are not just docile servants of a nation-state and (2) to claim that they are requires endorsing a Westphalian worldview that has become increasingly problematic.

Such objections, of course, fail to impress anyone who takes it for granted that an arms industry should be tied to a major political power because the latter needs its products to fulfill its global "responsibilities." A government thus exploiting people's resources to fund national defense can no doubt retain people's support provided they concur as to the identity of enemies and the need to fight them with weapons the arms industry provides. But if a declared enemy is neither a nation-state nor readily 
associable with a nation-state, Westphalian assumptions are less applicable, and political theorists begin talking about, say, "asymmetrical" conflicts.

Historically, the concept of "national defense" presupposed a Westphalian world in which nation states fight one another each purportedly to protect citizens for whom it is responsible. Throughout the era of colonization, of course, established nationstates sought to dominate people in places not deemed sovereign, and this continued during and after World War II (Porter, 1994, pp. 145-146). During the Cold War the West routinely subordinated smaller nations' claims to sovereignty to the global task of containing communism. To this end it treated the Soviet Union as an expansionary monolithic state seeking full control of places far removed from Russia or even its satellite countries. This bipolar worldview provided a credible Westphalian rationale for production and selective distribution of major weapons systems directly or indirectly under US control but put to use wherever a threat was identified.

Today, by contrast, the US proclaims its enemy to be not a super-state like the USSR but a stateless modus operandi whose base of operations may be anywhere. Purportedly in response to this threat, the US government seems committed to achieving and maintaining military supremacy in the world. Given this agenda, it is becoming more dependent on the arms industry than ever. And this situation, it would seem, undercuts the inseparability assumption and opens the contractor to CSR responsibilities. But since the Cold War ended, the US government has increasingly overlooked such responsibilities as it acquiesces in corporate priorities. To this end it is pursuing fiscal policies that risk engendering a major financial crisis. So why do American taxpayers let their government expose them to such great risk?

Two reasons predominate: lack of genuine democracy and lack of relevant information. A third is fear - not rational fear of quantifiable dangers to people's well-being, but a deliberately inculcated fear that enables the US government to fund the arms industry on a level that surpasses what all other countries combined spend on their "national defense." 5 This fear cannot be based on generic or hypothetical worries indefinitely, of course, but must eventually be tied to specific occupants of the world who are identified as enemies, meaning threats to US national security. Since the day in 2001 when non-state actors attacked a military and a corporate symbol of America's capitalist hegemony, the US government has claimed for itself just such identifiable enemies. It peremptorily called them terrorists, declared war on terrorism, and began carrying out long-planned encroachments on nation-states in the guise of fighting terrorism (Byrne, 2004, 2005; Dreyfuss, 2006). Congress dutifully endorsed open-ended funding of this war, and the media (with a few exceptions) dutifully adopted the supportive antiterrorism rhetoric without pausing to reflect. Reflection, however, is very much in order.

In this climate of manufactured opinion, only a few commentators (e.g., Mueller, 2006) have questioned the motives behind or the targets of this policy of spending the nation's wealth on weapons. Nor have many called attention to the inconsistent approach to justifying weapons procurement on the basis of assumptions that are alternatively Westphalian (against states that harbor terrorists) and postWestphalian (against terrorists who are non-state actors). Or that this was already being done during the Cold War era. For, then as now it was primarily the interests of certain private corporations rather than people near and far away that was being protected (Cousins, 1987). A full account of this history is beyond the scope of this essay; but my claim about the principal beneficiaries can be partially supported by recalling a moment in the history of US "defense" spending when some elected officials called that spending into question: the end of the Cold War.

The end of the Cold War quickly deflated the moralistic anti-communism raison-d'etre for US arms expenditures. At first arms manufacturers had no adequate response to the ethically appealing call for a "peace dividend" that would shift resources from weaponry to civilian priorities. As George Kennan had predicted, though (in Cousins, 1987, pp. 11-13), they were soon concocting new rationales. Not until the emergence of the open-ended war on terrorism a decade later, though, would there be another such cornucopian rationale. Recall, then, how anti-communism once played this role and then became ineffective.

World War I and especially World War II turned some US businesses into massive providers of military supplies and services (Cousins, 1987; Porter, 
1994, ch. 7) - what President Eisenhower famously labeled a "military-industrial complex." Its mission was to spend government money to defend capitalism while its foe spent a comparable amount in defense of communism. In practice this meant holding on to, and where possible bringing additional, territory under its dominion. To this end, each foe designed, tested, publicly funded, and built such technologically advanced weapons as electronically sophisticated warplanes, plutonium manufacturing plants, variably sited launching platforms, and espionage telecommunications. Meanwhile hot wars were fought primarily in less developed countries: 125 different wars between 1945 and 1991, resulting in the death of 40 million people, mostly civilians (Saul, 1992, pp. 141, 599). Why? In large part to help the superpowers as well as lesser powers determine who would control which strategic oil reserves, minerals, shipping lanes, military bases, and UN votes. These endeavors led largely to standoffs, and so also did the quest for technological superiority. In any event, the two superpowers were carrying a combined annual debt of $\$ 600$ billion when the Cold War ended (Dean and Clausen, 1988, p. 1). Who benefitted from this indebtedness? In the US, it was the weapons industry, at the expense of many people who were either taxed for or targeted by these weapons.

The principal Cold War era buyer of US-made weapons was the US government. The enemy was clearly identified, and weapons systems, including the Strategic Defense Initiative, were designed and targeted with "containment" in mind (Brody, 1987). To this end, many weapons had to be distributed to subservient defenders of US interests. This widespread provision of weapons was greatly accelerated in the 1960s when ex-Ford Motor Company CEO Robert McNamara used first DOD, then the World Bank to "rationalize" the US arms industry by maximizing production and selling "uniform" surplus to developing countries, largely on credit. This practice created a monetary crisis the response to which was to replace the Bretton Woods gold standard with a floating US dollar (Hobsbawm, 1994, pp. 473-474; Saul, 1992, pp. 81-99, 406-409). In the 1980s the global arms manufacturing industry, mostly in advanced capitalist countries, approached $\$ 1$ trillion per year in sales; some $\$ 140$ billion of this total went to less developed countries, with over half going to Middle East countries alone, especially Iraq and Saudi Arabia.

In the US, the Reagan administration excoriated communism in its rhetoric as it vastly expanded the weaponry-related budget. Defense contractors vied with one another for lucrative contracts, and over time developed complex illegal procedures to obtain and swap classified DOD plans and priorities on which they based their proposals. This endemic culture of illegality was eventually exposed, and a number of document thieves were convicted. For the sake of the supposed national interest, though, no contractor's special relationship with the Pentagon was suspended for any length of time (Pasztor, 1995).

In carrying out this "rearmament" program the US authorized exporting weapons almost everywhere, as did the other permanent members of the UN Security Council: France, China, Russia, and the UK. Together these countries (each of which has nuclear weapons capability) would supply $86 \%$ of all weaponry sold to poor countries in 1988-1992. ${ }^{6}$ But when the Cold War justification for defense spending came to an abrupt end, defense contractors had to face steep cuts in their revenues. Just days before the Gulf War began, for example, the US government cancelled a $\$ 57$ billion A-12 aircraft program on which defense contractors McDonnellDouglas and General Dynamics had been counting for a sizable part of their income. This setback, moreover, was symptomatic of the industry's overall diminution:

Where in 1985 the Pentagon had 497 aircraft weapons systems procurements, that number is just 55 today [1994]. For helicopters, the number has plummeted from 355 to 72 over the same period. Defense outlays, as a percentage of GDP, are projected to slip from 4.2 percent in 1994 to 2.9 percent in 1999. Broader social and economic trends will likely only accelerate this decline (Munro, 1994).

In 1990 , when the DOD had $\$ 300$ billion in its coffers, one think tank predicted the DOD budget would fall by a third by the year 2000 , and another said the government could save $\$ 500$ billion during the1990s "if the military [services'] competition 
were replaced by a cooperative reduction of armaments" (Kaufman, 1991, p. 47). Congressional budget makers took such ideas into account, and the arms business declined. So US military leaders began stressing external threats, including that posed by weapons systems already provided to potential problem countries, ${ }^{7}$ keeping supply lines open, and providing some global police service. They backed this up with seven scary eventualities, mostly associated with developing countries (Daly and Cobb, 1994, pp. 336-56; BW, 14 Jan. 1991, 3 Sept. 1990). And they tied continued military production to dual use and job preservation (both considered below). Such reasons in time prevailed, as sales to buyers in developing countries grew over the next decade to the point that they now account for well over 50\% of all arms transfer agreements made globally (Grimmett, 2005), regardless of all the challenges to human rights that this entails (Berrigan and Hartung, 2005). Meanwhile, defense contractors have been reinventing themselves through mergers and downsizing and have given more attention to commercial products. $^{8}$ I will illustrate these maneuvers in connection with Boeing Aircraft, but consider first how expansion of the dual use doctrine helped arms businesses adapt.

A dual-use technology is by definition developed for and identified with a military use but can also be used for a non-military purpose. The Internet is an example. So too is high resolution spy-satellite technology which, though developed by the Cold War principals to secretly keep track of one another's activities, can also be used to upgrade mapmaking, monitor environmental change, climate, narcotics, and immigration, and precisely position anything from commercial aircraft to a good place to catch fish. With this flexible usage in their marketing vocabulary, the Russians began selling their state-ofthe-art products to any buyer; and American defense contractors wanted to do the same. The Soviet Union's disintegration, though, diminished the incentive of many established consumers of US weapons to continue buying, ${ }^{9}$ and the US government still wanted to regulate weapons sales to suspect buyers. So US providers began emphasizing nonmilitary uses of their products and calling for "higher fences on fewer products," with the latter to constitute a "core list." But they still lacked a free market because of a mechanism the Western allies had established to control arms trade with the communist bloc.

This mechanism, known as the Coordination Committee for Multilateral Export Control (COCOM), had been set up in 1949 to monitor exports to countries behind the Iron Curtain. Then in 1991 COCOM loosened restrictions on imports into the old Soviet Union, and a year later enrolled Soviet successor states in the export control system. Decontrolled commodities came to include all but the most sophisticated computers, advanced machine tools and telecommunications; and the list of prohibited goods remained subject to "rapid modernization." Meanwhile companies involved in exporting dual use technologies increasingly neglected to request government authorization, even as impatient purchasers began looking elsewhere, especially to Europe, for military hardware. In response DOD became more attentive to the interests of home-based manufacturers. COCOM was abolished in 1992; and in 1994 thirty-three co-founding countries, including Russia and some of its former satellites, signed the Wassenaar Arrangement, a voluntary regime of after-the-fact reports on conventional arms sales (semi-annually) and sales of dual-use technologies (frequency depending on the sensitivity of the items sold and to whom).

This loosening of arms trade constraints is hardly all-inclusive, of course, by virtue of other treaty and statutory regimes pertinent to US arms exports. The US signed the Nuclear Nonproliferation Treaty (effective 1970), as have 188 other nation-states. And within the US numerous statutes are in place to regulate munitions exports, including in particular the Arms Export Control Act, which provides for State Department oversight of defense articles and services, and the Export Administration Act of 1979, which provides for Department of Commerce oversight of dual-use goods, software, and technology (some 12,000 applications per year). Three major lists of controlled items that establish licensing regimes are also in place - the Commerce Control List, the United States Munitions List, and the Nuclear Regulatory Commission Controls - and these are supplemented with ad hoc oversight provisions (US Department of State, n.d.). But not even nuclear nonproliferation has been enforced uniformly towards all developing countries. Recently, for example, the world's principal possessors of 
nuclear weapons threaten Iran and North Korea for seeking nuclear proficiency, but not Pakistan or India (not to mention Israel). Meanwhile, many non-nuclear weapons have been sold and distributed around the world; and controls on this trade are increasingly conspicuous by their absence. This can be seen from the following examples.

1. The International Military Education and Training (IMET) program was set up to introduce potential weapons users to available products on a try-before-you-buy basis. If as is often the case a participating country is short of funds Congress has taxpayers make up the difference (Hartung, 1999). For what purpose the trainees are going to use these weapons is seldom an issue, even if they come from countries at war or with abominable human rights records, e.g., Indonesia, Rwanda, Sierra Leone, Congo, Cote d'Ivoire. When the Indonesian military committed human rights abuses in East Timor, Congress banned them from IMET; but the DOD got around that by arranging "joint exercises" for US and Indonesian military.

2. An Excess Defense Articles (EDA) program, set up by the US Foreign Assistance Act in 1976, provides a mechanism whereby military services can dispose of unwanted weapons. EDA began to be used extensively after the end of the Cold War. In spite of a fair value requirement, the services gave $80 \%$ of their surplus weapons away free on an "as is, where is" basis (to hold down government costs) to a vastly expanded set of eligible purchasers. Soon weapons manufacturers protested that this bonanza stood in the way of their ability to sell similar weapons new. So a Commerce Department representative was added to those from the Departments of State and Defense on the EDA Coordinating Committee to protect their market (Pineo and Lumpe, 1996).

3. In 1997 the US House of Representatives unanimously adopted an "Arms Sales Code of Conduct" that would have allowed sales only to democratic countries that respect their citizens' human rights, are not aggressive towards other states, and participate fully in the UN Register of Conventional Arms. This provision was killed in conference committee. And no constraints were placed on the US Foreign Military Sales (FMS) program to distribute weapons of all kinds, usually gratis, to "friendly" (i.e., strategically useful) countries, including Somalia and Iraq.

4. US statutes bar transferring weapons or military aid to states that have been subjects of military coups; but a special law were passed exempting coup-governed Pakistan from these restrictions. Similarly, anyone involved in manufacturing, transferring, or delivering arms is prohibited from supplying terrorist states or regimes that display a "pattern of gross violations of internationally recognized human rights." In spite of these legal hurdles, exporters have with impunity shipped arms to countries known to be careless about human rights as well as to non-state actors of every sort. This is possible in part because of loopholes in the legislation, e.g., a provision that a financial institution is covered by restrictions only if "directly involved" in a transaction. Similarly, in 2001 the US Congress wanted to commit up to $\$ 300$ million for military assistance to the Northern Alliance and others in Afghanistan. Because of their involvement in human rights violations these groups were not eligible for such funding under existing law, so Congress inserted "notwithstanding any other provision of law" in their appropriations bill. ${ }^{10}$

5. Beginning in the 1990s a number of municipal governments in the US passed ordinances to hold weapons manufacturers liable for arms-related harm occurring within their jurisdictions. Several states then legislated against such ordinances; and in October 2005 two-thirds of the members of each Congressional body nationalized this hold-harmless immunization of the arms industry as The Protection of Lawful Commerce in Arms Act, and the President promptly signed it.

6. On the international level, especially at the $\mathrm{UN}$, various efforts to establish meaningful arms controls have so far been frustrated. As noted above, after years of effort the "Control Arms" campaign was recently blocked at 
a UN conference. Four years earlier a limited-scope UN Conference on the Illicit Trade in Small Arms and Light Weapons in All Its Aspects also failed (Karp, 2002), in part because participants focused not on human rights but on arms control, to which they assigned a low priority (Koh, 2003, p. 2347). These setbacks, in turn, are compounded by the failure of the UN Security Council, whose permanent members are major arms exporters, to fulfill its responsibility under Article 26 of the UN Charter to "formulat(e) ...plans to be submitted to the Members of the United Nations for the establishment of a system for the regulation of armaments."

One constant in all these strategies is a commitment to bolstering the arms industry, regardless of who gets hurt or how badly (Kwithy, 1979). Perhaps it is a jungle out there, as pro-gun lobbyists say, yet surely the unhampered distribution of weapons is not a civilizing factor. In particular, this process has become so complex that the respective roles of government agencies and private contractors are blurred. Hobbes would perhaps understand how this could be; but he would understand even more clearly the need to impose order on the chaos and assign responsibilities. Arguably this cannot be done effectively short of removing these corporations' limited liability either by reimposing charters or even nationalizing those that have become too autonomous (Cray and Drutman, 2004, 2005). Nothing of the sort has been done in the wake of $9 / 11$ as the executive branch seeks monarchical domination without undermining corporate prerogatives or generating much opposition.

Although their country had for years maintained a military presence in just about every part of the world and often encountered opposition, Americans saw themselves as the innocent victims of the highmortality acts committed on their soil. Lacking a cosmopolitan perspective regarding US foreign policy, they assumed that because they are good people anyone who did not love them must be bad. The US administration reinforced this simplistic outlook by elevating a scholar's assertion about a "clash of cultures" into a Manichean bipolarity that supports an imperialistic foreign policy. Soon it invaded Afghanistan, then Iraq, and threatened other countries, associating all these endeavors with a never defined, open-ended war on terrorism. Largely because of funding for this war the budget deficit of the US government, on an accrualaccounting basis, has reached $\$ 760$ billion (US Treasury, 2005; USA Today, 4 Aug. 2006), much of which is borrowed from and depends on foreign, especially Chinese, creditors. Many Americans stand to lose when this untenable state of affairs reaches crisis proportions. Who, then, stands to gain?

As in the past, the winners are the companies that do business with and through the DOD. Defense business is only one source of revenue for some of these companies. Others, however, depend on a steady input of defense contracts for their profitability if not their very existence. Included among these companies are most of the arms merchants that have been heavily funded for over sixty years. But due to various commercial, political, and technological changes, some new and restructured entities are now on the scene.

During the years 1997-2003 DOD worked with a budget totaling over $\$ 900$ billion. Over half of this total was spent on tens of thousands of private contractors who entered into some 2.2 million contracts. Eighty percent of these procurement dollars went to just 737 contractors; all but a hundred of them are American-owned. Over half of these awards now go for services rather than goods. The fifty biggest contractors took in more than half the money, and the top ten got 38 percent. ${ }^{11}$ Only one of these companies, Science Applications International, won its contracts through, in Pentagon terms, "full and open" competition. The preferred approach to gaining contracts is via campaign contributions and lobbying, both of which benefit from the endemic "revolving door" contacts of professional lobbyists. ${ }^{12}$ Embedded in these data is a huge structural change in the defense industry during the 1990s, namely, its compression into just a few major players. This industry, which included some 25 major contractors early in the decade, has since been reduced to just two giants, Boeing and Lockheed Martin, two other major contractors that are still trying to remain independent, Raytheon and Northrop Grumman, and a number of subcontractors and niche companies. This unprecedented reorganization was effected via mergers paid 
for by taxpayers and by the thousands of American workers who were the victims of outsourcing to China and Saudi Arabia just a few years after the major players had emphasized job maintenance in the 1992 election campaign. The most important of these mergers involved Boeing's purchase of Rockwell International's space and engine divisions in 1996 and its purchase of McDonnell Douglas in 1997. As a result of such changes at Boeing, this company is now the largest US arms exporter $(60 \%$ of its sales are to other countries). It so controls the Export-Import Bank that this institution is commonly referred to as the "Bank of Boeing," and its business connections with China have given it the single most important influence on US China policy (Parrish, 1999).

Boeing's singular prominence warrants briefly chronicling its role as a microcosm of the industry as a whole. Though heavily engaged in commercial business, it has consistently depended on DOD for a large percentage of its revenues, e.g., in 2004, 57\% of its revenues came from sales of military aircraft and weapons systems [AP, 28 Apr. 2004].) To garner this business it relies heavily on lobbyists, whose contract-seeking practices have periodically immersed the company in scandal. Recently, for example, the post- 9/11 "Boeing Boondoggle" emerged out of a provision in the December 2001 Pentagon appropriation bill authorizing the Air Force to lease a hundred 767 commercial jets at $\$ 20$ million per jet to use as refueling tankers - at a cost greater than the cost of purchasing the aircraft outright. Some heads rolled, the project was put on hold, and contractors began formulating plane replacement proposals. Boeing is now fighting a proposal to discontinue purchases of its $\mathrm{C}-17$ cargo planes ( $\$ 200$ million each) by pushing the unemployment button; and it looks forward to installing (as yet unreliable) antimissile interceptors in Poland to knock out (hypothetical) incoming missiles from Iran. And the sky would indeed be the limit if the US government does give China favored nation status as Boeing has been recommending so it can sell a vast fleet of planes there. ${ }^{13}$

The post-9/11 world has also introduced some new bidders for government contracts to provide products and services that will supposedly enhance US citizens' security. One major funding source in this new configuration is the Department of
Homeland Security (DHS), which the Bush administration initially opposed but has learned to love. DHS buys all sorts of purportedly safetyenhancing products from companies whose top personnel come increasingly from this new agency, where they earned far less than they do now in the private sector. Another newcomer is the foreignbased but largely American-owned arms manufacturer (e.g., the UK's BAE Systems) that challenges so-called Buy America rules and the domestic/foreign distinction by locating a plant in the US and/or buying US companies (NYT, 18 and 19 June 2006, 27 Sept. 2005).

From the perspective of the investors in and (surviving) employees of these companies, the ability of arms manufacturers to maintain a cozy relationship with US government funding sources is surely good news. But the victims of US military adventures, including taxpayers and US troops abroad, may not agree. Moreover, the DOD is both corrupt and incompetent as it goes about the business of fighting the war on terror. As reported by the Government Accounting Office (2006, p. $2)$, the DOD is vulnerable to contracting fraud, waste, and abuse (mismanagement) by virtue of weaknesses in each of five areas: "senior leadership, capable acquisitions workforce, adequate pricing, appropriate contracting approaches and techniques, and sufficient contract surveillance." Because of these weaknesses, no one in the Pentagon is held accountable when authorized weapons systems are not produced within designated time frames, or when their development goes as much as $50 \%$ over budget, or when such cost overruns require either reducing the number of units to be built or expanding defense spending beyond all rational limits. Contractors seem not to mind, though, because they are routinely paid regardless of their performance. This situation now has some members of Congress concerned enough to consider better oversight (NYT, 11 July 2006). But US government spokespersons divert attention from such problems by focusing rhetorically on the military's salvific mission. The mass media, now much more corporately controlled than during the Vietnam era or the Reagan administration, collaborate.

In short, the US national treasure is being expended for the sake of a comparatively small sector 
of the population, namely, people who benefit directly or indirectly from policies that commit two-thirds of the discretionary federal budget to "national defense." From within that budgetary bubble, some controversy is aroused when the ritual of stateside base closings is underway, and now also when the DHS announces its state-by-state distribution of counter-terrorism funds. But these economic concerns are embedded in a culture that exalts the quality-of-life benefits that flow from militarism, however unfounded this perception might be (Michalos, 1989).

What these factual data reveal, unfortunately, is that the American people are accustomed to letting militaristic rhetoric trump moral concerns. When the mantra of national defense is sounded they see no moral issue to address despite the concentration of tax-derived funds on the arms industry. Yet what US taxpayers contribute to this industry is second only to their support of agriculture. Some elected representatives have dared ask why. Not only to protect people, industry spokespersons reply, but to give them good jobs. Perhaps so, but whatever employment the industry provides could be accomplished just as well by subsidies to other industries. Besides, the actual number of citizens employed is minimized by offsets (on-site manufacturing) and outsourcing to client buyers abroad.

Neither capitalist nor communist ideology could defend this boondoggle in the name of national defense. But so long as the world and its inhabitants do not go up in a mushroom cloud, Americans seem unperturbed by the many lesser cataclysms effected in their name - by, e.g., cluster bombs, computer guided missiles, and helicopter gun ships. This moral blindness is understandable considering how carefully it is being crafted, partly by politicians and media but perhaps even more by arms industry advertisers and lobbyists. In some quarters this situation might be regarded as a criminal conspiracy. But Westphalian mythology diverts people's attention from the efforts of peace-oriented NGOs to impose humanitarian values on the military weapons industry. Considering this industry's performance with respect to either the CSR profitability requirement or the CSR use of political power requirement, companies in the arms industry should not be immune from liability by virtue of their relationship to a (debatably) sovereign state.

\section{Conclusion}

I have found that the US arms industry is in violation of CSR standards regarding the environment, social equity, profitability, and use of political power. This finding is of no concern to anyone unable to look beyond Westphalian assumptions, which render a violence facilitator blameless if it is acting at the behest of a sovereign government. But if these assumptions are disallowed an arms manufacturer should not be able to disavow its CSR inadequacies by simply pointing to government priorities.

In a blueprint Westphalian nation-state, the government exercises hegemony over violence whether within or beyond its borders. In practice, though, this hegemony is not wholly the prerogative of government. In the US an arguably individualoriented constitutional right to bear arms renders the government's designations of friends and foes irrelevant in the absence, say, of some felonious behavior or terrorist connections (Cottrol, 1994). But precisely because of this libertarian bias regarding weapons possession in the US, a case can be made that in the domestic market arms manufacturers are not just agents but are principals in the provision of weapons to users. Similarly, given the political power of US arms manufacturers and the defects in US government controls over arms transfers, some liability for the harm caused by US-produced weapons that are used abroad should be assigned to their manufacturers if the latter arrange transfers knowing the likely consequences of their action.

Assigning liability to arms manufacturers for harm caused at home or abroad seems, then, altogether appropriate if the range of their activity in a political system manifests a high degree of autonomy. This contention would be challenged, of course, by anyone who is persuaded that whatever arms manufacturers produce is for the sake of national defense. It would also be challenged by anyone who questions the propriety of treating use of political power as a CSR criterion. Can these challenges be taken seriously, though, if their proponents do not offer some alternative way to address the violations of human rights that these companies' products facilitate? The immensity of such violations would be incalculable if brought about by major weapons systems, but these are now built more for corporate revenue than for actual military use. Human rights 
violations are, however, being brought about de facto with small arms, which are being used far too much without justification.

So whether we contextualize this problem of liability within or beyond the nation-state, a corporation should not be said to be acting responsibly if it unhesitatingly transfers weapons to any group expressing a need whether government guidelines preclude the transfer or not. For, these weapons are rarely placed in museums as objets d'art. Rather do their purchasers use them as means to power and wealth over the bodies of anyone who stands in their way. This blood-drenched reality suggests a need to reconsider the justification for assigning limited liability to any corporation regardless of its products' negative externalities. The present system of token government oversight is, in short, no substitute for comprehensive cost-benefit analyses and human rights standards that take peoples' lives and wellbeing into account. If such constraints were in place and could avoid capture by those it regulated, at least small arms manufacturers and traders would be seen for what they are and what they constructively intend to be: facilitators of death and destruction.

\section{Notes}

1 To economists, an externality is any effect of a transaction between two parties on a third party who is not involved in the carrying out of that transaction. If the externality is a benefit it is positive; if it is a cost, it is negative. Some consider only externalities from one market to another (e.g., reduction of fish population due to pesticide runoff from a farm). As I use this term it extends beyond identifiable markets to anything of value, human or not, even if not readily quantifiable.

2 NYT here and hereafter stands for The New York Times, and Econ for The Economist. Other news sources to be cited are: Business Week, BW; Associated Press, AP; International Herald-Tribune; IHT; In These Times, ITT; World Press Review, WPR.

3 Elan (2004, p. 25), Dex Media (2003), Genelabs Technologies, Inc. (2004), Northwestern Energy (2005), Reinhold (n.d., p. 8), Starwood Hotels and Resorts Worldwide, Inc. (2004, sect. 20, pp. 47-48) and Thomson (n.d.).

4 Fifth Third Bank (2001), Ballard Power Systems, Inc. (n.d., 4.0 and 5.0), Cabot Oil and Gas Corp. (2005, sect. V). Dynegy (2004), Global Crossing (2005),
Lucent Technologies (n.d.), NiSource (n.d., Workplace IV) and State Farm (2006).

5 The US defense budget came to $\$ 538-48$ billion in 2004 but grows to $\$ 765.5$ billion if one includes other defense-related expenditures that are funded outside the Department of Defense, e.g., in the Department of Energy (nuclear weapons) or the Veterans Administration. That year total expenditures for defense in the rest of the world came to $\$ 509$ billion. see SIPRI, 2005, p. 310; Brauer and Anglewicz 2005; Wheeler 2006.

6 Econ, 23 July, 4 June, and 12 Feb. 1994, 18 Dec. 1993, 23 March 1991; BW, 13 June 1994; ITT, 11 July 1994; WPR, Sept. 1992.

7 ITT, 11 July 1994, 15 Nov. 1993, 13 June 1994; BW, 9 Nov. 1992; NYT, 20 Sept. 1992; 17 Feb. 1992; 2 Feb. 1992.

8 BW, 20 Sept. 1993, p. 88; NYT, 17 Jan. 1993, p. 3:1+; 4 Oct. 1992, p. F5; 9 Dec. 1990, p. F5; WSJ, 15 July 1994, p. A1+.

9 Sunday Times (London), 26 Nov. 1989; Independent (London), 22 Jan. 1990; Figaro, 3-4 March 1990; 7 March 1990; 5 March 1990; IHT, 6 Feb. 1990.

10 The statutes at issue here were: Sections 116 and $502 \mathrm{~b}$ of the Foreign Assistance Act of 1961; Section 508 of the FY2002 Foreign Operations Appropriations Act; Section 40 of the Arms Export Control Act of 1976, 22 U.S.C. sect 2778(b), as amended 1996; and the Leahy Amendment to the Foreign Assistance Act and the Defense Appropriation Act. See Amnesty International, 2006, pp. 5, 35.

11 These top ten contractors and the amounts of their contracts over FY 1998-2003 were (not counting joint venture income): Lockheed-Martin (\$94 billion), Boeing (\$81.6 billion), Raytheon (\$39.9 billion), Northrop Grumman ( $\$ 33.9$ billion), General Dynamics ( $\$ 33.2$ billion), United Technologies (\$17.8 billion), General Electric ( $\$ 10.6$ billion), Science Applications International (\$10.5 billion), and Newport News Shipbuilding ( $\$ 8.8$ billion), now owned by Northrop-Grumman.

12 Four of the top six spenders on lobbying over the fiveyear period (the others being Altria and AT\&T) were top defense contractors: General Electric (\$88.million), Lockheed Martin (\$71.5 million), Boeing (\$64.4 million), and Northrop Grumman (\$61.2 million) (Knott, 2004; Makinson, 2004).

13 NYT, 22 and 24 May 2006; Mobile Press-Register, 13 June 2006.

\section{References}

Amnesty International, TransArms: 2006, 'Dead on Time - Arms Transportation, Brokering and the Threat to Human Rights', 10 May, online at http:// web.amnesty.org/library/index/engact300082006. 
Ardley, J. and A. Grant: n.d., 'The Environmental Consequences of War', Sierra Club of Canada, online at http://www.sierraclub.ca/national/postings/ war-and-environment.html.

Baker, M.: 2005, 'Can companies that make products that kill be socially responsible?', Business Respect no. 86 (10 Sept.), online at http://www.mallenbaker.net/csr/ CSRfiles/page.php?Story_ID=1492.

Ballard Power Systems, Inc.: n.d., 'Corporate Governance, Code of Ethics and Workplace Guidelines Policy', online at http://www.ballard.com/resources/ documents/CODEOFETHICS.pdf.

Berrigan, F. and W. D. Hartung: 2005, 'U.S. Weapons at War 2005: Promoting Freedom or Fueling Conflict?', World Policy Institute, June, online at http://www.worldpolicy. org/projects/arms/reports/wawjune2005.html.

Brauer, J.: 2000, 'The Effect of War on the Natural Environment', online at http://www.aug.edu/ sbajmb/ paper-london3.PDF.

Brauer, J. and N. Anglewicz, 'Two-Thirds on Defense', Tom Paine, 10 June 2005, reposted on Global Policy Forum website.

Brenkert, G. G.: 2000, 'Social Products Liability: The Case of the Firearms Manufacturers', Business Ethics Quarterly 20(1), 21-32.

Brenkert, G. G.: 1999, 'The Case of the Contested Firearms', Business and Society Review 104(4), 347354.

Brody, H.: 1987, 'Star Wars: Where the Money's Going', High Technology Business, Dec. 1987, pp. 22-29.

Byrne, E. F.: 2006, 'Leave No Oil Reserves Behind, Including Iraq's: The Geopolitics of American Imperialism', T. Smith and H. Van der Linden (eds.), Radical Philosophy Today 4, forthcoming.

Byrne, E. F.: 2005, 'The 2003 U.S. Invasion of Iraq: Militarism at the Service of Geopolitics', in A. W. Eickelmann, T. Lansford and E. Nelson (eds.), Justice and Violence: Political Violence, Pacifism and Cultural Transformation (Ashgate Press, Aldershot), pp. 193-216.

Byrne, E. F.: 2004, 'The Post-9/11 State of Emergency: Reality versus Rhetoric', in C. Hughes (ed.), Social Philosophy Today 19 (Philosophy Documentation Center, Charlottesville, VA), pp. 193-215.

Cabot Oil and Gas Corp.: 2005, 'Code of Business Conduct', online at http://www.caborog.com/pdf/ GovernCodeConduct.pdf.

Carroll, A. B.: 1991, 'The Pyramid of Corporate Social Responsibility: Toward the Moral Management of Organizational Stakeholders', Business Horizons 34, 39-48.

Center for Defense Information (CDI): 2006, 'Power of NRA Showcased in U.S. Delegation to Small Arms
Conference', June 26, online at http://www.cdi.org/ program/index.cfm?programid $=23$. .

Centre for Humanitarian Dialogue (CHD): 2006, 'International Law and Small Arms and Light Weapons Control: Obligations, Challenges and Opportunities," Briefing Paper (Centre for Humanitarian Dialogue, Geneva), online at http://www.smallarmsnet.org/ workshops/IntLawAndSmallArmsMar06.pdf.

Collins, J. C. and J. I. Porras: 2002, Built to Last: Successful Habits of Visionary Companies (HarperBusiness, New York).

R. E. Cottrol: 1994, Gun Control and the Constitution: Sources and Explorations on the Second Amendment (Garland, New York).

Cousins, N.: 1987, The Pathology of Power (Norton, New York).

Cray, C. and L. Drutman: 2005, 'Corporations and the Public Purpose: Restoring the Balance', Seattle Journal for Social Justice, vol 4, issue 1 (Fall/Winter), online at http://www.law.seattleu.edu/sjsj/2005fall/cray.

Cray, C. and L. Drutman: 2004, The People's Business: Controlling Corporations and Restoring Democracy (Berrett-Koehler, San Francisco).

Crook, C.: 2005, 'The Good Company: A Survey of Corporate Social Responsibility', The Economist, 22 Jan.

Daly, H. E. and J. B. Cobb, Jr.: 1994, For the Common Good, 2nd Edition (Beacon Press, Boston).

Davis, K.: 1960, 'Can Business Afford to Ignore Social Responsibilities?', California Management Review 2(3), 70-76.

Dean, J. and P. Clausen: 1988, The INF Treaty and the Future of Western Security (Union of Concerned Scientists, Cambridge, MA).

Dex Media: 2003, 'Code of Business Ethics and Conduct', online at http://media.corporate-ir.net/ media.files/irol/14/148542/reports/CodeBusinessEthicsConduct.pdf.

Doane, D.: 2005, 'The Myth of CSR', onPhilanthropy, as posted on the Global Policy Forum web site.

Dreyfuss, R.: 2006, 'Next We Take Tehran', Mother Jones, July-Aug., pp. 59-61.

Dynegy: 2004, 'Code of Business Conduct and Ethics: Turning Words into Ethical Actions', rev., online at http://www.dynegy.com/downloads/ Dynegy_Code_of_Business_Conduct_and_Ethics.pdf.

ECOSOC (United Nations Economic and Social Council): 2003, 'United Nations Norms on the Responsibility of Transnational Corporations and Other Enterprises with Regard to Human Rights', E/ CN.4/Sub.2/2003/12/Rev.2.

Elan: 2004, 'Code of Conduct', online at http:// www.elan.com. 
Elm, N.: 1998, 'The Business of Unethical Weapons', Business Ethics: A European Review 7:1 (Jan.), pp. 25-29.

Environmental and Occupational Risk Management (EORM): n.d., 'People, Planet, Profit: The Value of Corporate Social Responsibility', Priority Press ed. No. 8, online at http://www.eorm.com/ezine/pp8/ csr.asp.

Farah, D. and S. Braun: 2006, 'The Merchant of Death', Foreign Policy Magazine (Nov/Dec), pp. 38-47.

Fifth Third Bank: 2001, 'Code of Business Conduct and Ethics', online at http://www.53.com/wcm/resources/ file/eb27ed01a81b721/About53_IR_codeofbusinessconductandethics.pdf.

Gariépy, N.: 2001, 'Lac Saint-Pierre, Quebec', UNESCO Biosphere Reserves in Canada, No. 13, online at http:/ / www.biosphere_canada.ca/publications/newlettersbulletins/ 13/art.1.htm.

Garriga, E. and D. Melé: 2004, 'Corporate Social Responsibility Theories: Mapping the Territory', Journal of Business Ethics 53, 51-71.

Genelabs Technologies, Inc.: 2004, 'Code of Business Ethics and Conduct', online at http://www.genelabs. com/ir/CodeofConduct.htm/\#Weapons_and_Workplace_Violence.

General Dynamics: n.d., 'General Dynamics Ethics and Conduct: Standards of Business Ethics and Conduct', online at http://www.gdeb.com'suppliers/sect_1/ doc_7/page_1.pdf.

Gettler, L.: 2005, 'Liability Forges a New Morality', The Age, 3 Aug., online at http://www.globalpolicy.org/ IntJustice/atca/2005/0803morality.htm.

Global Crossing: 2005, 'Code of Ethics and Business Conduct', online at http://www.globalcrossing.com/ pdf/investors/inv_ethics.pdf.

Goldberg, E.: 2001, 'Profit, People, Planet; Policy Issues \& Options Around Triple Bottom Line Reporting', online at http://www.mfe.govt.nz/publications/sus-dev/ profit-people-feb01.pdf.

Goldring, N.: 1999, 'The NRA Goes Global', Bulletin of the Atomic Scientists Jan.-Feb., 61-65.

Gowri, A.: 2004, 'When Responsibility Can't Do It', Journal of Business Ethics 54, 33-50.

Graafland, J. J., S. C. W. Eijiffinger and H. SmidJohan: 2004, 'Benchmarking of Corporate Social Responsibility: Methodological Problems and Robustness", Journal of Business Ethics 53(1-2), 137-152.

Grimmett, R. F.: 2005, 'Conventional Arms Transfers to Developing Nations, 1997-2004', Report for Congress, U.S. Congressional Research Service, Library of Congress, 29 Aug., online at http://www.fas.org/ man/crs/RL32547.pdf.

Harigel, G. G.: 2001, 'Chemical and Biological Weapons: Use in Warfare, Impact on Society and Environment',
Nuclear Age Peace Foundation, online at http:// www.wagingpeace.org/articles/2001/11/00_harigel_ ebw.htm.

Hartung, W. D.: 2001, 'The New Business of War: Small Arms and the Proliferation of Conflict', Ethics and International Affairs 15(1), 79-96.

Hartung, W. D.: 1999, 'Corporate Welfare for Weapons Makers: The Hidden Costs of Spending on Defense and Foreign Aid,' Policy Analysis No. 350, 12 Aug., online at http://www.cato.org/pubs/pas/pa350.pdf .

Hartung, W. D.: 1988, 'The Arms Traders: Weapons for the World', Multinational Monitor 9:2 (Feb.).

Heath, J. and W. Norman: 2005, 'Stakeholder Theory, Corporate Governance and Public Management: What Can the History of State-Run Enterprises Teach Us in the Post-Enron Era?', Journal of Business Ethics 53(3), 247-265.

Henderson, D.: 2005, 'The Role of Business in the World Today', online at http://www.greenleadpublishing.com/pdfs/jcc1hen.pdf.

Hobsbawm, E.: 1994, The Age of Extremes: The Short Twentieth Century 1914-1991 (Abacus, London).

Hopkins. M.: 2004, 'Corporate Social Responsibility: An Issue Paper', Working Paper No. 27 (International Labour Office, Policy Interpretation Department, Geneva), online at http://www.ilo.org/public/english/ bureau/integration/download/publicat/ 4_3_285_wcsdg-wp-27.pdf.

Hopkins, M.: 2003, The Planetary Bargain: Corporate Social Responsibility Matters (Earthscan, London).

Hopkins, M., and I. Hopkins: 2002, 'Labour Standards and Corporate Social Responsibility: The Need for a Bargain', online at http://www.adb.org/Documents/Events/2002/ Core_Labor_Standards/hopkins_paper.pdf.

Jeurissen, R: 2004, 'Institutional Conditions of Corporate Citizenship', Journal of Business Ethics 53(1-2), 87-96.

Kapelus, P: 2004, 'Mining, Corporate Social Responsibility and the "Community": The Case of Rio Tinto, Richards Bay Minerals and the Mbonambi', Journal of Business Ethics 39(3), 275-296.

Karp, A.: 2002, 'Laudable Failure', SAIS Review 13(1), 177-193.

Kaufman, W. W.: 1991, Glasnost, Perestroika, and U.S. Defense Spending (Brookings Institution, Washington, DC).

Klare, M.: 1999, 'The Kalashnikov Age', Bulletin of the Atomic Scientists 55:1 (Jan./Feb.), pp. 18-22.

Knott, A.: 2004, 'The Pentagon's Stealth Rainmaker: How revolving doors and large donations allow a defense lobbying firm to dominate', Center for Public Integrity, online at http://wwwpublicintegrity.org/ pus $/$ report.aspx?aid $=388$. 
Koh, H.: 2003, 'Lecture: The Robert L. Levine Distinguished Lecture Series: A World Drowning in Guns', Fordham Law Review 71, 2333-2362.

Linklater, A.: 1998, The Transformation of Political Community: Ethical Foundations of the Post-Westphalian Era (University of South Carolina Press, Columbia).

London, T.:2005, 'Small Arms and Corporate Social Responsibility: Emerging International Norms and a Program for Advocacy', online at http://www. ploughshares.ca/libraries/WorkingPapers/wp051.pdf.

Lucent Technologies: n.d., 'Business Guideposts: A Personal Commitment', online at http://www. lucent.com/social/pdf/guideposts.pdf.

Makinson, L.: 2004, 'Outsourcing the Pentagon: Who Benefits from the Politics and Economics of National Security?', 29 Sept. (The Center for Public Integrity), online at http://www.publicintegrity.org/pns/report/ aspx?aid $=385$.

Matten, D., A. Crane and W. Chapple: 2003, 'Behind the Mask: Revealing the True Face of Corporate Citizenship', Journal of Business Ethics 45, 109-120.

Michalos, A.: 1989, Militarism and the Quality of Life, Canadian Papers in Peace Studies, No. 1 (Science for Peace, University of Toronto, Toronto).

Misol, L.: 2004, 'Weapons and War Crimes: The Complicity of Arms Suppliers,' Human Rights Watch Report, online at http://hrw.org/wr2k4/13.htm.

Mnutsakanian, R.: 1997, 'A Poisoned Legacy', Our Planet 8:6 (March), online at http://www.ourplanet.com/ imqversn/86/sakan.html. .

Mokhiber, R. and R. Weissman: 2005, 'Hijacked', online at http://lists.essential.org/pipermail/corp-focus/2005/ 000220.html.

Morton, D: 2006, 'Gunning for the World', Foreign Policy Jan.-Feb., 58-67.

Mueller, J.: 2006, 'Is There Still a Terrorist Threat? The Myth of the Omnipresent Enemy', Foreign Affairs Sept.-Oct., 2-8.

Munro, N.: 1994, 'The Peace Deficit', Washington Technology, 15 Sept., online at http://www.washingtontechnology.com/news/9_11/news/9146-1.html.

NiSource: n.d., 'Business Ethics Program and the Code of Integrity Handbook', online at http://ir. nisource.com/governance/integrity.cfm?PageSection=4\#.

Northwestern Energy: 2005,' Code pf Business Conduct and Ethics', online at http://www.northwesternenergy.com/documents/Code_Conduct.pdf.

Parrish, G.: 1999, 'US Arms Exporters: Boeing', Mother Jones Mojowire, online at http://www.motherjones.com/news/special_reports/arms/boeing.html.

Pasztor, A.: 1995, When the Pentagon Was for Sale: Inside America's Biggest Defense Scandal (Scribner, New York).
Pava, M. L. and J. Krausz: 1997, 'Criteria for Evaluating the Legitimacy of Corporate Social Responsibility', Journal of Business Ethics 16(3), 337-347.

Peluso, N. L. and M. Watts: 2001, Violent Environments (Cornell University Press, Ithaca).

Pineo, P. F. and L. Lumpe: 1996, 'Recycled Weapons: American Exports of Surplus Arms, 1990-1995’ (Federation of American Scientists, Arms Sales Monitoring Project, Washington), online at http:// www.fas.org/asmp/library/publications/recycle.htm.

Porter, B.D.: 1994, War and the Rise of the State: The Military Foundations of Modern Politics (Free Press, New York).

Reinhold: n.d., 'Reinhold Business Ethics and Code of Conduct', online at http://www.reinhold-ind.com/ pdf/business_ethics.pdf.

Saul, J. R.: 1992, Voltaire's Bastards: The Dictatorship of Reason in the West (Penguin, Maryborough, Australia)

Shah, A.: 2006, 'Arms Trade - A Major Cause of Suffering', online at http://www.globalissues.org/ Geopolitics/Arms/Trade/BigBusiness.asp.

Singer, P.: 2003, Corporate Warriors (Cornell University Press, New York).

Starwood Hotels \& Resorts Worldwide, Inc.: 2004, 'Worldwide Code of Conduct and Business Ethics', online at http://media.corporate-ir.net/media_files/ NYS/HOT/governance/code0904.pdf.

State Farm: 2006, '2006 State Farm Code of Conduct', online at http://www.statefarm.com/media/intro_code.htm.

Stockholm International Peace Research Institute (SIPRI): 2005, SIPRI Yearbook 2005: Armaments, Disarmament and International Security (Oxford University Press, Oxford).

Sturm, Ruger \& Company, Inc.: n.d., 'Code of Business Conduct and Ethics, online at http://www. ruger-firearms.com/Corporate/PDF/Code $\% 20 \%$ Ethics. pdf Sturm, Ruger \& Company, Inc.: n.d., 'Code of Business Conduct and Ethics, online at http:// www.ruger-firearms.com/Corporate/PDF/Code $\% 20 \%$ Ethics.pdf.

Thomson: n.d., 'Code of Business Conduct and Ethics', online at http://www.thomson.com/cons/assets/pdfs/ corporate/corporate_governance/English_101a.pdf.

U.S. Department of State, Bureau of Nonproliferation: n.d., 'An Overview of U.S. Export Controls', online at http://www.exportcontrol.org/, click on 'Export Control'.

U.S. Treasury: 2005, '2005 Financial Report of the United States Government', online at fms.treas.gov/fr/ index.html.

Vogel, D.: 2005, The Market for Virtue: The Potential and Limits of Corporate Social Responsibility (Brookings Institution, Washington, DC). 
Wagner, C. G.: 2003, 'War Crimes Against Nature: Groups Raise Call to Arms Against War on the Environment', The Futurist 37:3 (May-June).

Wheeler, W.: 2006, 'Just How Big Is the Defense Budget?' CounterPunch, 19 Jan., online at www.counterpunch. org/wheeler.01192006.html.

Windsor, D.: 2006, 'Corporate Social Responsibility: Three Key Approaches', Journal of Management Studies 43:1 (Jan.), pp. 93-113.

Wood, B.: 2006, 'A Dirty Trade in Arms', Le Monde diplomatique, June, online at http://mondedplo.com/ 2006/06/10dirtytrade.
Wood, D. J.: 1991, 'Corporate Social Performance Revisited', Academy of Management Review 16, 691-718. Zwetsloot, G. I. J. M.: 2003, 'From Management Systems to Corporate Social Responsibility', Journal of Business Ethics 44(2-3), 201-208.

Indiana University, 5 Riverpointe Road, Hastings-on-Hudson, NY 10706, U.S.A. E-mail: ebyrne@iupui.edu 